\title{
Activated MET acts as a salvage signal after treatment with alectinib, a selective ALK inhibitor, in $A L K$-positive non-small cell lung cancer
}

\author{
AKIHIRO KOGITA $^{1,2^{*}}$, YOSUKE TOGASHI ${ }^{*}$, HIDETOSHI HAYASHI $^{1,3}$, ERI BANNO ${ }^{1}$, MASATO TERASHIMA $^{1}$, \\ MARCO A. DE VELASCO ${ }^{1}$, KAZUKO SAKAI ${ }^{1}$, YOSHIHIKO FUJITA ${ }^{1}$, SHUTA TOMIDA $^{1}$, \\ YOSHIFUMI TAKEYAMA ${ }^{2}$, KIYOTAKA OKUNO ${ }^{2}$, KAZUHIKO NAKAGAWA ${ }^{3}$ and KAZUTO NISHIO ${ }^{1}$ \\ Departments of ${ }^{1}$ Genome Biology, ${ }^{2}$ Surgery and ${ }^{3}$ Medical Oncology, \\ Kinki University Faculty of Medicine, Osaka 589-8511, Japan
}

Received October 8, 2014; Accepted November 25, 2014

DOI: $10.3892 /$ ijo.2014.2797

\begin{abstract}
Non-small cell lung cancer (NSCLC) carrying echinoderm microtubule-associated protein-like 4 (EML4)anaplastic lymphoma kinase $(A L K)$ rearrangements is hypersensitive to ALK inhibitors, including crizotinib and alectinib. Crizotinib was initially designed as a MET inhibitor, whereas alectinib is a selective ALK inhibitor. The MET signal, which is inhibited by crizotinib but not by alectinib, is dysregulated in many human cancers. However, the role of the MET signal in $A L K$-positive NSCLC remains unclear. In this study, we found that hepatocyte growth factor (HGF), ligand of MET, mediated the resistance to alectinib, but not to crizotinib, via the MET signal in $A L K$-positive NSCLC cell lines (H3122 and H2228 cell lines). In addition, alectinib activated the MET signal even in the absence of HGF and the inhibition of the MET signal enhanced the efficacy of alectinib. These findings suggest that activated MET acts as a salvage signal in $A L K$-positive NSCLC. This novel role of the MET signal in $A L K$-positive NSCLC may pave the way for further clinical trials examining MET inhibitors.
\end{abstract}

\section{Introduction}

Lung cancer is the leading cause of cancer-related death for both men and women worldwide (1). Non-small cell lung cancer (NSCLC) accounts for $\sim 80 \%$ of lung cancers and the

Correspondence to: Professor Kazuto Nishio, Department of Genome Biology, Kinki University Faculty of Medicine, 377-2 Ohno-higashi, Osaka-Sayama, Osaka 589-8511, Japan

E-mail:knishio@med.kindai.ac.jp

*Contributed equally

Key words: non-small cell lung cancer, EML4-ALK rearrangement, alectinib, crizotinib, MET prognosis of patients with advanced NSCLC remains very poor despite advances in treatment (2).

For most individuals with advanced NSCLC, cytotoxic chemotherapy is the mainstay of treatment based on the moderate improvement in survival that it confers. However, the outcome of chemotherapy in such patients has reached a plateau in terms of the response rate (25-35\%) and overall survival period (OS; $8-10$ months) $(3,4)$. One promising treatment strategy involves the further subdivision of NSCLC into clinically relevant molecular subsets according to a classification schema based on specific so-called oncogenic driver mutations. These mutations occur in genes that encode signal proteins crucial for cellular proliferation and survival. Thus, cancer might rely on the expression of these single oncogenes for survival. This concept is also called oncogene addiction (5). The most prevalent mutated or rearranged oncogenes identified in NSCLC are $K R A S$, epidermal growth factor receptor $(E G F R)$, anaplastic lymphoma kinase $(A L K)$, and ROS1, among others (6). The identification of EGFR mutations as one type of oncogenic driver mutation in a subset of patients with NSCLC, coupled with the development of EGFR tyrosine kinase inhibitors (EGFR-TKIs), has opened new ways to treat this disease (7-10). Recently, a novel fusion transcript with transforming activity that is formed by the translocation of echinoderm microtubuleassociated protein-like 4 (EML4) (2p21) and $A L K(2 \mathrm{p} 23)$ has been described in a subset of NSCLCs (11). The EML4-ALK rearrangement has been identified in 5-10\% of NSCLC cases and ALK inhibitors have shown marked antitumor effects in such tumors (11-14). However, some of these tumors are resistant to inhibitors and acquired resistance to ALK inhibitors has been already found to limit the therapeutic potential of these agents (15-17); thus, investigations of more effective strategies are warranted.

Crizotinib was the first clinically available ALK inhibitor for $A L K$-positive NSCLC in the world. This drug, however, was initially designed as a MET inhibitor and also exhibits ROS1 and RON kinase inhibitory activity (18). In contrast, secondgeneration ALK inhibitors (i.e., alectinib and ceritinib) are selective ALK inhibitors that are effective against second-site 
mutations of the $A L K$ domain that induce resistance to crizotinib (19-21). The MET signal, which is inhibited by crizotinib but not by alectinib, is dysregulated in many human cancers and promotes tumor growth, invasion and dissemination. Abnormalities in the MET signal are reportedly correlated with poor clinical outcomes and drug resistance in patients with cancer, including lung cancer (22-25). Especially, MET amplification and its ligand, hepatocyte growth factor (HGF), have been observed in EGFR-mutated NSCLC cells that are resistant to EGFR-TKIs $(26,27)$. In $A L K$-positive NSCLC, however, the role of the MET signal remains unclear. In the present study, the role of the MET signal in $A L K$-positive NSCLC, especially its inhibition by alectinib, was investigated.

\section{Materials and methods}

Cell cultures, ligands and reagents. The $\mathrm{H} 3122$ and $\mathrm{H} 2228$ cell lines (NSCLC cell lines with EML4-ALK rearrangements) were maintained in RPMI-1640 medium with $10 \%$ FBS (Sigma-Aldrich, St. Louis, MO, USA). HGF was purchased from R\&D Systems (Minneapolis, MN, USA). Crizotinib and alectinib (ALK inhibitors) and PHA-665752 (a MET inhibitor) were purchased from Selleck Chemicals (Houston, TX, USA).

In vitro growth inhibition assay. The growth-inhibitory effects were examined using a 3, 4, 5-dimethyl-2H-tetrazolium bromide assay (MTT; Sigma-Aldrich), as described previously (28). Briefly, $180 \mu \mathrm{l} /$ well of the cell suspension $(2,000 /$ well $)$ was seeded onto 96 -well microculture plates and incubated in $10 \%$ FBS-containing medium for $24 \mathrm{~h}$. The cells were treated with crizotinib or alectinib at various concentrations and were cultured at $37^{\circ} \mathrm{C}$ in a humidified atmosphere for $72 \mathrm{~h}$. When the influence of $\mathrm{HGF}$ was investigated, the ligand $(10 \mathrm{ng} / \mathrm{ml})$ was added at the same time. After the culture period, $20 \mu \mathrm{l}$ of MTT reagent were added and the plates were further incubated for $2 \mathrm{~h}$. After centrifugation of the plates, the culture medium was discarded and the wells were filled with dimethyl-sulfoxide. The absorbance of the cultures at $570 \mathrm{~nm}$ was measured using VERSAmax (Japan Molecular Devices, Tokyo, Japan). The experiment was performed in triplicate.

Antibody. Antibodies specific for ALK, phospho-ALK, MET, phospho-MET, EGFR, phospho-EGFR, HER2, phosphoHER2, AKT, phospho-AKT, ERK1/2, phospho-ERK1/2 and $\beta$-actin were obtained from Cell Signaling (Beverly, MA, USA).

Western blot analysis. A western blot analysis was performed as described previously (28). Briefly, subconfluent cells were washed with cold phosphate-buffered saline (PBS) and harvested with lysis A buffer containing 1\% Triton X-100, $20 \mathrm{mM}$ Tris- $\mathrm{HCl}$ (pH 7.0), $5 \mathrm{mM}$ EDTA, $50 \mathrm{mM}$ sodium chloride, $10 \mathrm{mM}$ sodium pyrophosphate, $50 \mathrm{mM}$ sodium fluoride, $1 \mathrm{mM}$ sodium orthovanadate and the protease inhibitor mix Complete ${ }^{\mathrm{TM}}$ (Roche Diagnostics; Basel, Switzerland). Whole-cell lyses were separated using SDS-PAGE and were blotted onto a polyvinylidene fluoride membrane. After blocking with $3 \%$ bovine serum albumin in a TBS buffer (pH 8.0) with $0.1 \%$ Tween-20, the membrane was probed with the primary antibody. After rinsing twice with TBS buffer, the membrane was incubated with a horseradish peroxidaseconjugated secondary antibody and washed, followed by visualization using an ECL detection system and LAS-4000 (GE Healthcare, Buckinghamshire, UK).

Real-time reverse transcription PCR (RT-PCR). One microgram of total RNA from cultured cell lines was converted to cDNA using the GeneAmp RNA-PCR kit (Applied Biosystems, Foster City, CA, USA). Real-time PCR was performed using SYBR Premix Ex Taq and Thermal Cycler Dice (Takara, Shiga, Japan), as described previously (29). The glyceraldehyde 3-phosphate dehydrogenase (GAPD, NM_002046) gene was used to normalize the expression levels in subsequent quantitative analyses. The experiment was performed in triplicate. To amplify the target genes encoding HGF and MET, the following primers were used: $H G F-\mathrm{F}$, TTAAACTCCTGGCCT CAAGCAATC; $H G F-\mathrm{R}$, TCCTATCTTGGGCAAAGCAA CTG; MET-F, TGAGTACCGGAGACAGGTGCAG; and $M E T$-R, TAGCAGCTTCAACGGCAAAGTTC.

Statistical analysis. Continuous variables were analyzed using the Student's t-test and the results were expressed as the average and standard deviations (SD). The statistical analyses were two-tailed and were performed using Microsoft Excel (Microsoft, Redmond, WA, USA). A P-value of $<0.05$ was considered statistically significant.

\section{Results}

HGF induced resistance to alectinib but not to crizotinib. Crizotinib exhibits MET inhibitory activity, but alectinib does not. Then, HGF, a MET ligand, can be associated with resistance to alectinib, but not to crizotinib, via the MET signal. To examine the influence of HGF, the sensitivities of H3122 and H2228 cell lines to crizotinib or alectinib were tested with or without HGF (10 ng/ml) using an MTT assay. Both cell lines were sensitive to crizotinib, even in the presence of HGF, whereas these cell lines were resistant to alectinib in the presence of HGF (Fig. 1A). The 50\% inhibitory concentrations $\left(\mathrm{IC}_{50}\right)$ of crizotinib were 0.10 without HGF and 0.11 with HGF in the $\mathrm{H} 3122$ cell line and 0.48 without $\mathrm{HGF}$ and $0.58 \mu \mathrm{M}$ with HGF in the H2228 cell line, respectively (Table I). The $\mathrm{IC}_{50}$ values of alectinib were 0.023 without $\mathrm{HGF}$ and 0.61 with $\mathrm{HGF}$ in the $\mathrm{H} 3122$ cell line and 2.26 without $\mathrm{HGF}$ and $8.95 \mu \mathrm{M}$ with HGF in the $\mathrm{H} 2228$ cell line, respectively.

Crizotinib, but not alectinib, inhibited the MET signal activated by $H G F$. Next, to investigate the influence of HGF on the MET signal, western blot analyses were performed. The cells were treated with ALK inhibitors for $3 \mathrm{~h}$ and HGF was added $30 \mathrm{~min}$ before sample collection. Alectinib $(0.05 \mu \mathrm{M})$ did not inhibit the phosphorylation of MET activated by HGF $(10 \mathrm{ng} / \mathrm{ml})$, whereas crizotinib $(0.1 \mu \mathrm{M})$ inhibited HGF-induced MET phosphorylation (Fig. 1B). HGF also phosphorylated two downstream signals, AKT and ERK and this phosphorylation was cancelled by crizotinib, but not by alectinib. These findings indicated that HGF is associated with resistance to a selective ALK inhibitor, alectinib, but not to crizotinib in $A L K$-positive NSCLC via the MET signal. 
A
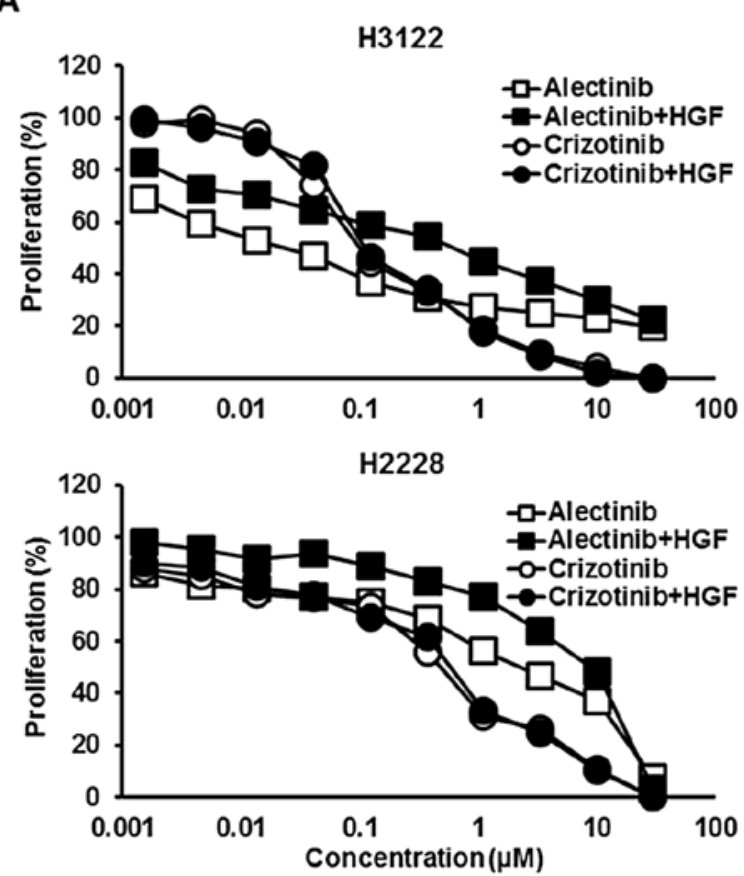

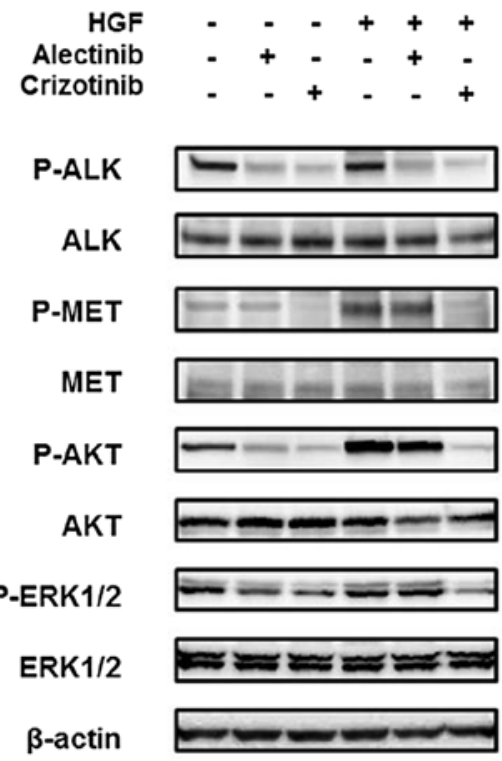

Figure 1. Sensitivities to ALK inhibitors (crizotinib and alectinib) in $A L K$-positive cell lines with or without HGF and western blot analyses. (A) Growth inhibitory effect in the H3122 and H2228 cell lines. To examine the sensitivity of ALK inhibitors, we used an MTT assay; HGF was used at a concentration of $10 \mathrm{ng} / \mathrm{ml}$. The experiment was performed in triplicate. HGF induced resistance to alectinib in both cell lines. In contrast, it did not induce resistance to crizotinib. Lines, mean of independent triplicate experiments. (B) Western blot analyses in the H3122 cell line. The cells were treated with ALK inhibitors for $3 \mathrm{~h}$ and HGF was then added $30 \mathrm{~min}$ before sample collection. Alectinib and crizotinib were used at concentrations of 0.05 and $0.1 \mu \mathrm{M}$, respectively. Alectinib did not inhibit the HGF-induced phosphorylation of MET, whereas crizotinib inhibited the phosphorylation. HGF also phosphorylated two downstream signals, AKT and ERK, and these effects were cancelled by crizotinib, but not by alectinib.

Table I. $\mathrm{IC}_{50}$ values of alectinib and crizotinib with or without HGF.

\begin{tabular}{lccccc}
\hline & \multicolumn{2}{c}{$\mathrm{H} 3122$} & & \multicolumn{2}{c}{ H2228 } \\
\cline { 2 - 3 } \cline { 5 - 6 } \cline { 5 - 6 } & HGF $(-)$ & HGF $(+)$ & & HGF (-) & HGF (+) \\
\hline Crizotinib $(\mu \mathrm{M})$ & 0.10 & 0.11 & & 0.48 & 0.58 \\
Alectinib $(\mu \mathrm{M})$ & 0.023 & $0.61^{\mathrm{a}}$ & & 2.26 & $8.95^{\mathrm{a}}$ \\
\hline
\end{tabular}

$\mathrm{IC}_{50}, 50 \%$ inhibitory concentration; HGF, hepatocyte growth factor.

Alectinib activates the MET signal even without $H G F$. To investigate the long-term influence of ALK inhibitors on the MET signal, western blot analyses were performed in a timedependent manner. Three hours after treatment with alectinib $(0.05 \mu \mathrm{M})$, the phosphorylation of MET was not changed (Fig. 1B), whereas longer alectinib treatment periods (12, 24 or $48 \mathrm{~h}$ ) activated the MET signal (Fig. 2). Furthermore, downstream signals, such as AKT and ERK, were also activated along with the activated MET signal. In contrast to alectinib, crizotinib $(0.1 \mu \mathrm{M})$ did not activate but instead inhibited the MET signal (Fig. 2B). These findings suggest that the MET signal is activated after treatment with alectinib, even in the absence of HGF. The mRNA expression levels of $H G F$ and $M E T$ examined using real-time RT-PCR did not change after alectinib treatment (data not shown). Previous studies have
A

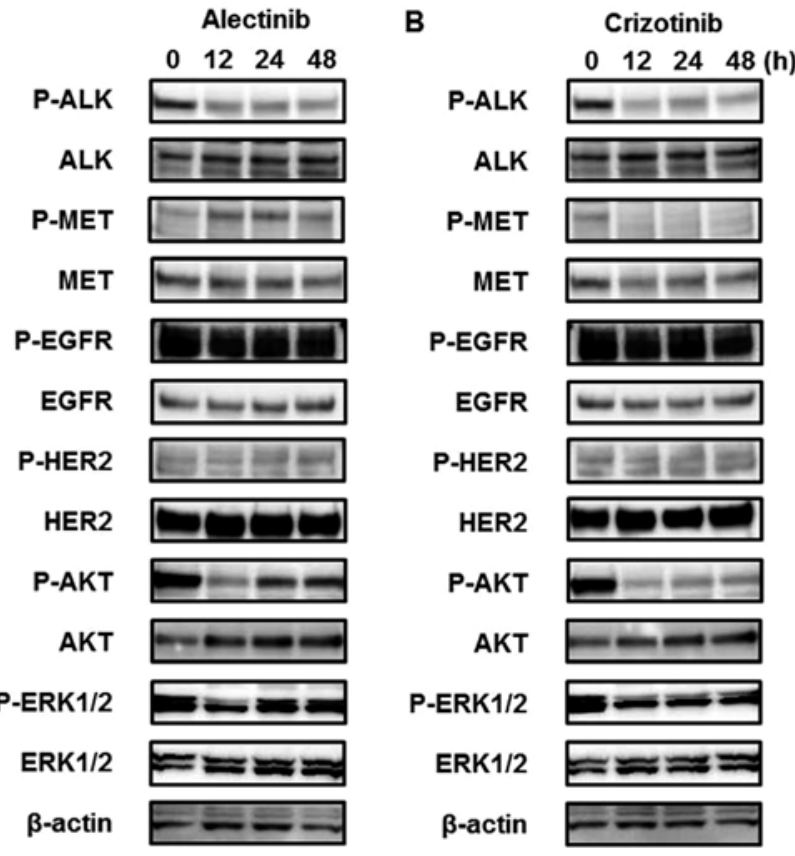

Figure 2. Time-dependent western blot analyses after treatment with ALK inhibiters in the H3122 cell line. Alectinib (A) and crizotinib (B) were used at concentrations of 0.05 and $0.1 \mu \mathrm{M}$, respectively; HGF was not administered. Both alectinib and crizotinib decreased the phosphorylation of ALK. In contrast, long-term treatment with alectinib $(12,24$ or $48 \mathrm{~h})$ increased the phosphorylation of MET. Furthermore, two downstream signals, AKT and ERK, were also activated, along with the activated MET signal. In contrast to alectinib, crizotinib did not activate but instead inhibited the MET signal. The phosphorylation of HER family was unchanged. $\beta$-actin was used as an internal control. 
A

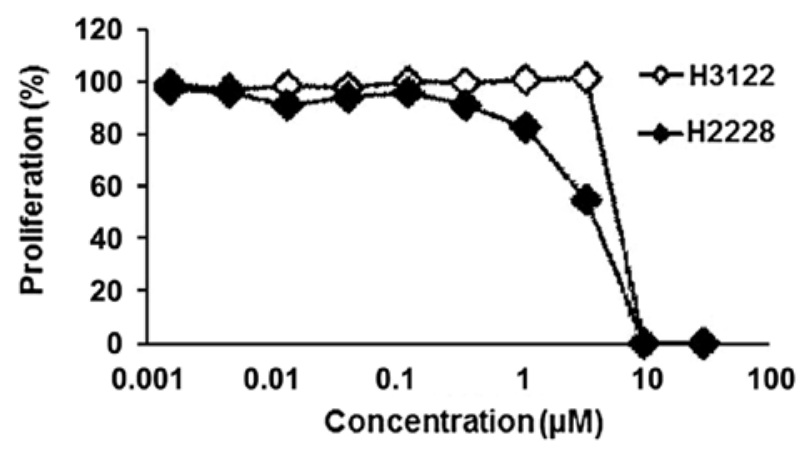

B

H3122
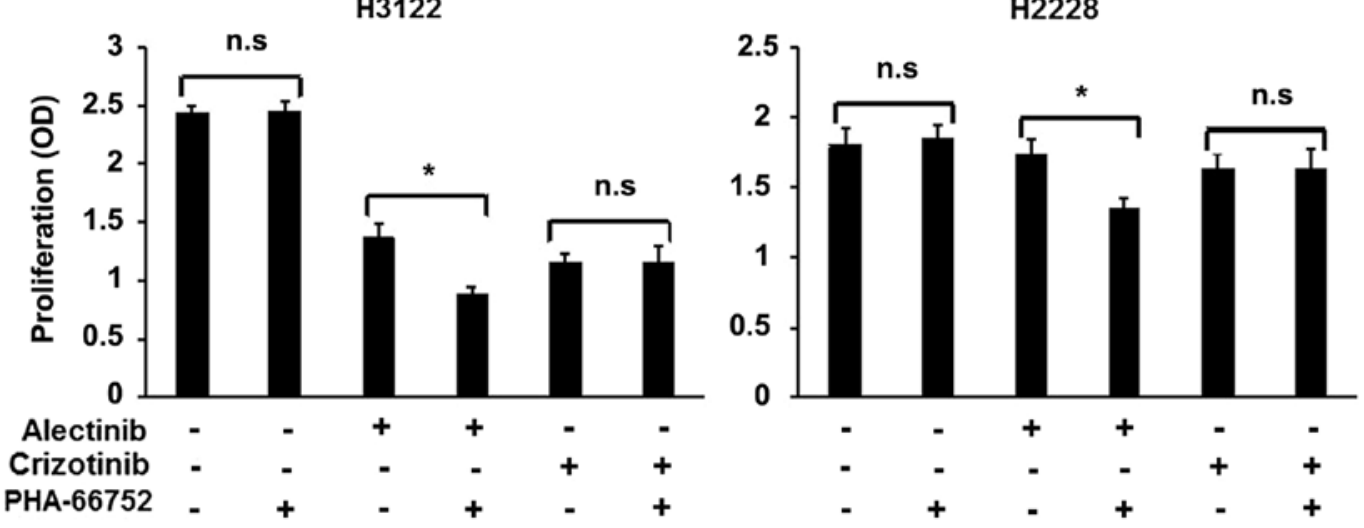

Figure 3. Combination therapy with a MET inhibitor in $A L K$-positive cell lines. To examine the synergistic effect of a MET inhibitor (PHA-66752), we used an MTT assay. (A) Sensitivity of the $A L K$-positive cell lines to PHA-66752. Both the H3122 and H2228 cell lines were not sensitive to PHA-66752. The IC values of $\mathrm{H} 3122$ and $\mathrm{H} 2228$ were 5.83 and $3.68 \mu \mathrm{M}$, respectively. Lines, mean of independent triplicate experiments. (B) Synergistic effect of ALK inhibitors and a MET inhibitor. Alectinib, crizotinib and PHA-66752 were used at concentrations of $0.05,0.1$ and $0.5 \mu \mathrm{M}$, respectively. PHA-66752 alone did not influence proliferation in either the $\mathrm{H} 3122$ or $\mathrm{H} 2228$ cell line. In contrast, PHA-66752 enhanced the efficacy of alectinib, but not of crizotinib, in both cell lines. Columns, mean of independent triplicate experiments; error bars, $\mathrm{SD} ;{ }^{*} \mathrm{P}<0.05$.

A

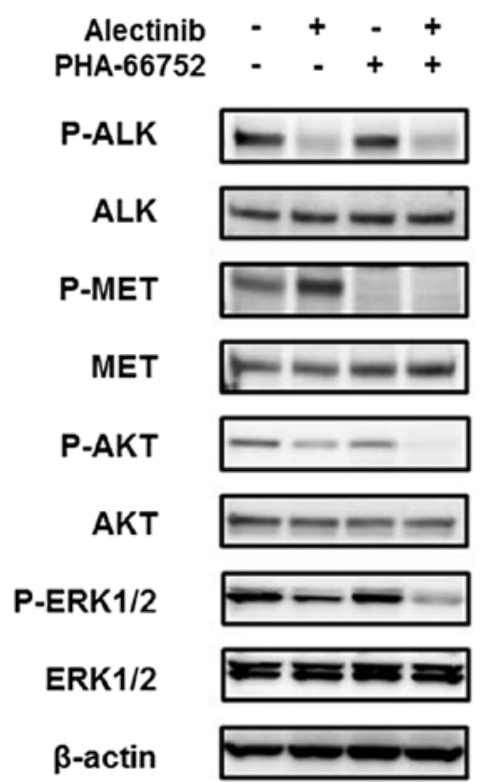

B

Crizotinib -+++
PHA-66752 $-4++$
P-ALK
ALK
P-MET
P-AKT
P-ERT
ERK1/2
B-actin

Figure 4. Western blot analyses for the combination of ALK inhibitors and a MET inhibitor in the H3122 cell line. Alectinib, crizotinib, and PHA-66752 were used at concentrations of $0.05,0.1$ and $0.5 \mu \mathrm{M}$, respectively. The cells were treated with the inhibitors for $12 \mathrm{~h}$ before sample collection. (A) Effect of alectinib and a MET inhibitor (PHA-66752). Alectinib alone decreased the phosphorylation of ALK but increased the phosphorylation of MET. PHA-66752 alone did not influence the phosphorylation of ALK but decreased the phosphorylation of MET. The combination decreased the phosphorylation of both ALK and MET, resulting in greatly decreased downstream signals (AKT and ERK). $\beta$-actin was used as an internal control. (B) Effect of crizotinib and a MET inhibitor (PHA-66752). Crizotinib alone decreased the phosphorylation of both ALK and MET. PHA-66752 alone did not influence the phosphorylation of ALK but decreased the phosphorylation of MET. The combination effect on ALK, MET and downstream signals was similar to that of crizotinib alone. $\beta$-actin was used as an internal control. 


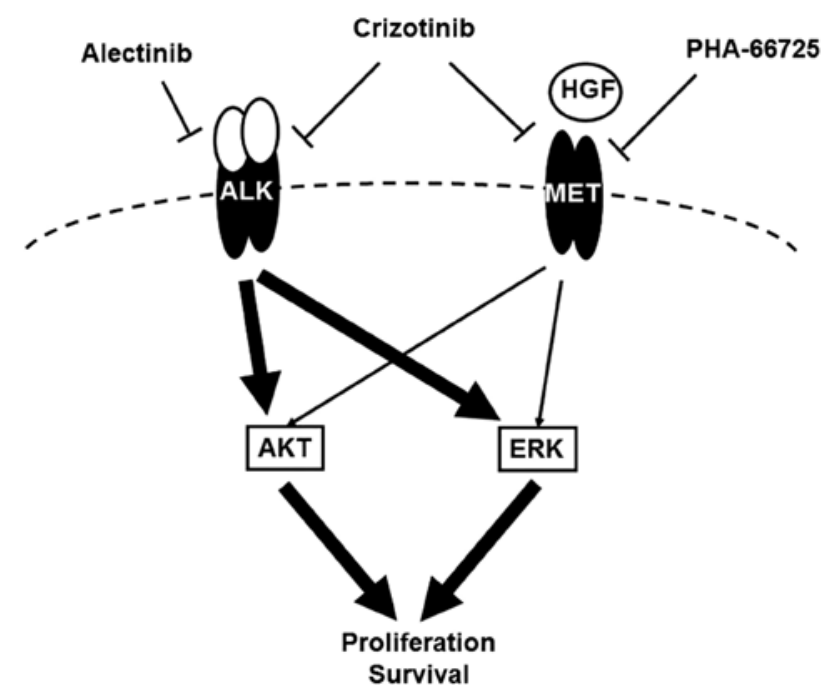

Figure 5. Diagram for the proposed effects of ALK and MET signals. The MET signal salvages the proliferation and survival of $A L K$-positive NSCLC after the inhibition of the ALK signal. Alectinib can inhibit only the ALK signal, whereas crizotinib can inhibit both the ALK and MET signals.

shown that HER signals are related to resistance to ALK inhibitors $(30,31)$ and these signals exhibit crosstalk with the MET signal (22-24). Therefore, the phosphorylation of EGFR and HER2 were investigated, but no changes were observed (Fig. 2).

A MET inhibitor enhances the efficacy of alectinib. To determine whether the inhibition of the activated MET signal enhances the efficacy of alectinib, combination therapy consisting of alectinib and a MET inhibitor, PHA-66752, was evaluated. Neither of the cell lines was sensitive to PHA-66752, with $\mathrm{IC}_{50}$ values of 5.83 and $3.68 \mu \mathrm{M}$ for the $\mathrm{H} 3122$ and $\mathrm{H} 2228$ cell lines, respectively (Fig. 3A). PHA-66752 (0.5 $\mu \mathrm{M})$ alone did not inhibit the cellular growth of the H3122 and H2228 cell lines, but its combination with alectinib enhanced the efficacy of alectinib (Fig. 3B). In contrast to alectinib, the combination of PHA-66752 and crizotinib did not enhance the efficacy of crizotinib (Fig. 3B). Western blot analyses revealed that the phosphorylation of MET at $12 \mathrm{~h}$ after treatment with alectinib was inhibited by PHA-66752, and the AKT and ERK downstream signals were also inhibited (Fig. 4A). Because the phosphorylation of MET was inhibited by crizotinib, the addition of PHA-66752 had no effect on the MET and downstream signals (Fig. 4B). These findings indicated that the inhibition of the activated MET signal enhanced the efficacy of alectinib, but not of crizotinib.

\section{Discussion}

Alectinib has been identified as a potent, selective, ALK inhibitor that is effective against most second-site mutations of the $A L K$ domain, notably L1196M and C1156Y, with a 10 -fold stronger potency than crizotinib $(19,20)$. This drug was tested in a phase I/II study that enrolled $46 A L K$-positive crizotinibnaive Japanese patients; a response rate of $94 \%$ was reported and the drug seemed to have fewer adverse events than those associated with crizotinib (14). Therefore, in the future, this drug might play a central role in the treatment of $A L K$-positive NSCLC. Crizotinib, the first available ALK inhibitor, exhibits MET inhibitory activity, whereas alectinib does not exert such an activity (18). In this study, we found that HGF mediated resistance to alectinib, but not to crizotinib, via the MET signal, that alectinib activated the MET signal even in the absence of HGF and that the inhibition of MET enhanced the efficacy of alectinib in $A L K$-positive NSCLC cell lines. To the best of our knowledge, this is the first study to discuss the role of the MET signal in $A L K$-positive NSCLC.

Uncontrolled cell survival, growth, angiogenesis and metastasis are essential hallmarks of cancer (32). HGF and its receptor, MET, have a causal role in all of these processes, thus providing a strong rationale for targeting these molecules in cancer. In addition, the MET signal has been frequently implicated in resistance to targeted therapies (22-25). Especially, $M E T$ amplification and its ligand, $\mathrm{HGF}$, are found in EGFR-mutated NSCLC cells that are resistant to EGFR-TKIs $(26,27)$. ALK-positive NSCLC resistant to crizotinib includes secondary $A L K$ mutations, $A L K$ gene amplification, the activation of other kinases and the epithelial-mesenchymal transition (15-17,30,33). To overcome these mechanisms, second-generation ALK inhibitors, HSP90 inhibitors and combinations with other kinase inhibitors have been tried. In contrast to EGFR-TKI or alectinib, crizotinib exhibits MET inhibitory activity; therefore, resistance associated with the MET signal has not been reported. Because of the absence of MET inhibitory activity, the resistance to alectinib may be associated with the MET signal and we found that HGF mediated the resistance to alectinib, but not to crizotinib, via the MET signal. Similar to our present study, a previous study revealed that fibroblast-derived HGF-induced MET activation caused resistance to TEA658 (another ALK inhibitor without MET inhibitory activity) but not to crizotinib (34). Most human cancers are composed of cancer cells that coexist with a variety of extracellular matrix components and cell types, including fibroblasts. Therefore, alectinib might be less effective in such environments. Moreover, without HGF stimulation, the MET signal was activated after the treatment of alectinib and the inhibition of the activated MET signal enhanced the efficacy of alectinib. Indeed, a case of alectinib resistance induced by $M E T$ amplification has been reported and a recent study showed that $A L K$-positive NSCLC exhibited a high level of MET expression $(35,36)$. These findings suggest that the MET signal can salvage the growth and survival of $A L K$-positive NSCLC after the inhibition of the ALK signal (Fig. 5). The expressions of HGF and MET after treatment with alectinib were unchanged. Several crosstalk mechanisms between MET and other signals have been reported (22-24) and the phosphorylation of HER family was investigated, but no changes were observed. MET interaction with many other membrane receptors has been reported and a recent study demonstrated that EGR1, a transcription factor, could sustained MET signal after ALK inhibition $(24,37)$. We speculate that these might be associated with our findings.

Extensive preclinical work has been done on MET inhibitors, including monoclonal antibodies and kinase inhibitors and this work has led to further clinical trials examining these agents (22-25). Clinical trials of combination therapy with EGFR-TKIs in patients with acquired resistance to EGFR- 
TKIs have also been performed. Our experiments showed that the MET signal salvaged the growth and survival of $A L K$-positive NSCLC after treatment with a selective ALK inhibitor, which might play a central role in the treatment of $A L K$-positive NSCLC. In addition, the inhibition of the MET signal enhanced the efficacy of a selective ALK inhibitor. These findings are expected to promote novel clinical trials of MET inhibitors.

In conclusion, we found that HGF mediated resistance to alectinib, but not to crizotinib, via the MET signal, that alectinib activated the MET signal even in the absence of HGF and that the inhibition of MET enhanced the efficacy of alectinib in $A L K$-positive NSCLC cell lines. These findings suggest that activated MET acts as a salvage signal in $A L K$-positive NSCLC. This novel role of the MET signal in $A L K$-positive NSCLC may pave the way for further clinical trials examining MET inhibitors.

\section{Acknowledgements}

We thank Mr. Shinji Kurashimo, Mr. Yoshihiro Mine, Ms. Eiko Honda, Ms. Tomoko Kitayama, and Ms. Ayaka Kurumatani for their technical assistance. We thank Dr P.A. Jänne (Department of Medical Oncology, Dana-Farber Cancer Institute, Boston, MA, USA) for providing the $\mathrm{H} 3122$ cell line. This study was supported by the Third-Term Comprehensive 10-Year Strategy for Cancer Control and Grant-in Aid for Japan Society for Promotion of Science Fellows.

\section{References}

1. Siegel R, Naishadham D and Jemal A: Cancer statistics, 2013. CA Cancer J Clin 63: 11-30, 2013.

2. Siegel R, DeSantis C, Virgo K, et al: Cancer treatment and survivorship statistics, 2012. CA Cancer J Clin 62: 220-241, 2012.

3. Schiller JH, Harrington D, Belani CP, et al: Comparison of four chemotherapy regimens for advanced non-small-cell lung cancer. N Engl J Med 346: 92-98, 2002.

4. Ohe Y, Ohashi Y, Kubota K, et al: Randomized phase III study of cisplatin plus irinotecan versus carboplatin plus paclitaxel, cisplatin plus gemcitabine, and cisplatin plus vinorelbine for advanced non-small-cell lung cancer: Four-Arm Cooperative Study in Japan. Ann Oncol 18: 317-323, 2007.

5. Weinstein IB: Cancer: addiction to oncogenes - the Achilles heal of cancer. Science 297: 63-64, 2002.

6. Pao W and Girard N: New driver mutations in non-small-cell lung cancer. Lancet Oncol 12: 175-180, 2011.

7. Paez JG, Janne PA, Lee JC, et al: EGFR mutations in lung cancer: correlation with clinical response to gefitinib therapy. Science 304: 1497-1500, 2004

8. Lynch TJ, Bell DW, Sordella R, et al: Activating mutations in the epidermal growth factor receptor underlying responsiveness of non-small-cell lung cancer to gefitinib. N Engl J Med 350: 2129-2139, 2004.

9. Pao W, Miller V,Zakowski M, et al: EGF receptor gene mutations are common in lung cancers from 'never smokers' and are associated with sensitivity of tumors to gefitinib and erlotinib. Proc Natl Acad Sci USA 101: 13306-13311, 2004.

10. Mok TS, Wu YL, Thongprasert S, et al: Gefitinib or carboplatinpaclitaxel in pulmonary adenocarcinoma. N Engl J Med 361: 947-957, 2009.

11. Soda M, Choi YL, Enomoto M, et al: Identification of the transforming EML4-ALK fusion gene in non-small-cell lung cancer. Nature 448: 561-566, 2007.

12. Kwak EL, Bang YJ, Camidge DR, et al: Anaplastic lymphoma kinase inhibition in non-small-cell lung cancer. N Engl J Med 363: 1693-1703, 2010.

13. Shaw AT, Kim DW, Nakagawa K, et al: Crizotinib versus chemotherapy in advanced ALK-positive lung cancer. N Engl J Med 368: 2385-2394, 2013.
14. Seto T, Kiura K, Nishio M, et al: CH5424802 (RO5424802) for patients with ALK-rearranged advanced non-small-cell lung cancer (AF-001JP study): a single-arm, open-label, phase 1-2 study. Lancet Oncol 14: 590-598, 2013.

15. Choi YL, Soda M, Yamashita Y, et al: EML4-ALK mutations in lung cancer that confer resistance to ALK inhibitors. N Engl J Med 363: 1734-1739, 2010.

16. Katayama R, Shaw AT, Khan TM, et al: Mechanisms of acquired crizotinib resistance in ALK-rearranged lung Cancers. Sci Transl Med 4: 120ra17, 2012.

17. Katayama R, Khan TM, Benes C, et al: Therapeutic strategies to overcome crizotinib resistance in non-small cell lung cancers harboring the fusion oncogene EML4-ALK. Proc Natl Acad Sci USA 108: 7535-7540, 2011.

18. Cui JJ, Tran-Dubé M, Shen H, et al: Structure based drug design of crizotinib (PF-02341066), a potent and selective dual inhibitor of mesenchymal-epithelial transition factor (c-MET) kinase and anaplastic lymphoma kinase (ALK). J Med Chem 54: 6342-6363, 2011.

19. Sakamoto H, Tsukaguchi T, Hiroshima S, et al: CH5424802, a selective ALK inhibitor capable of blocking the resistant gatekeeper mutant. Cancer Cell 19: 679-690, 2011.

20. Kodama T, Tsukaguchi T, Yoshida M, Kondoh O and Sakamoto H: Selective ALK inhibitor alectinib with potent antitumor activity in models of crizotinib resistance. Cancer Lett 351: 215-221, 2014.

21. Friboulet L, Li N, Katayama R, et al: The ALK inhibitor ceritinib overcomes crizotinib resistance in non-small cell lung cancer. Cancer Discov 4: 662-673, 2014.

22. Peters S and Adjei AA: MET: a promising anticancer therapeutic target. Nat Rev Clin Oncol 9: 314-326, 2012.

23. Gherardi E, Birchmeier W, Birchmeier C and Vande Woude G: Targeting MET in cancer: rationale and progress. Nat Rev Cancer 12: 89-103, 2012.

24. Corso S and Giordano S: Cell-autonomous and non-cell-autonomous mechanisms of $\mathrm{HGF} / \mathrm{MET}$-driven resistance to targeted therapies: from basic research to a clinical perspective. Cancer Discov 3: 978-992, 2013.

25. Sadiq AA and Salgia R: MET as a possible target for non-smallcell lung cancer. J Clin Oncol 31: 1089-1096, 2013.

26. Engelman JA, Zejnullahu K, Mitsudomi T, et al: MET amplification leads to gefitinib resistance in lung cancer by activating ERBB3 signaling. Science 316: 1039-1043, 2007.

27. Yano S, Wang W, Li Q, et al: Hepatocyte growth factor induces gefitinib resistance of lung adenocarcinoma with epidermal growth factor receptor-activating mutations. Cancer Res 68: 9479-9487, 2008.

28. Arao T, Fukumoto H, Takeda M, Tamura T, Saijo N and Nishio K: Small in-frame deletion in the epidermal growth factor receptor as a target for ZD6474. Cancer Res 64: 9101-9104, 2004.

29. Matsumoto K, Arao T, Hamaguchi T, et al: FGFR2 gene amplification and clinicopathological features in gastric cancer. Br J Cancer 106: 727-327, 2012.

30. Tanizaki J, Okamoto I, Okabe T, et al: Activation of HER family signaling as a mechanism of acquired resistance to ALK inhibitors in EML4-ALK-positive non-small cell lung cancer. Clin Cancer Res 18: 6219-6226, 2012.

31. Yamaguchi N, Lucena-Araujo AR, Nakayama S, et al: Dual ALK and EGFR inhibition targets a mechanism of acquired resistance to the tyrosine kinase inhibitor crizotinib in ALK rearranged lung cancer. Lung Cancer 83: 37-43, 2014.

32. Hanahan D and Weinberg RA: Hallmarks of cancer: the next generation. Cell 144: 646-674, 2011.

33. Kim HR, Kim WS, Choi YJ, Choi CM, Rho JK and Lee JC: Epithelial-mesenchymal transition leads to crizotinib resistance in H2228 lung cancer cells with EML4-ALK translocation. Mol Oncol 7: 1093-1102, 2013.

34. Yamada T, Takeuchi S, Nakade J, et al: Paracrine receptor activation by microenvironment triggers bypass survival signals and ALK inhibitor resistance in EML4-ALK lung cancer cells. Clin Cancer Res 18: 3592-3602, 2012.

35. Feng Y, Minca EC, Lanigan C, et al: High MET receptor expression but not gene amplification in ALK 2 p23 rearrangement positive non-small-cell lung cancer. J Thorac Oncol 9: 646-653, 2014.

36. Gouji T, Takashi S, Mitsuhiro T and Yukito I: Crizotinib can overcome acquired resistance to CH5424802: is amplification of the MET gene a key factor? J Thorac Oncol 9: e27-e28, 2014.

37. Voena C, Di Giacomo F, Panizza E, et al: The EGFR family members sustain the neoplastic phenotype of $\mathrm{ALK}^{+}$lung adenocarcinoma via EGR1. Oncogenesis 2: e43, 2013. 